"Commencing at a point, $S$. thirty-two degrees thirty minutes W. one and sixty-five hundredths chains from the N.W. corner of the S.W. quarter of section two $T$. seventy-eight $N$. of $R$. twenty-four $W$.; thence $N$. seventy-four degrees thirty scconds $E$. six hundred and eighty feet to a stone; thence $S$. fifteen degrees thirty seconds $E$. three hundred and sixty feet to a stone; thence $S$. seventy-four degrees thirty seconds W. six hundred and eighty feet to a stone; thence $N$. fifteen degrees thirty seconds $W$. three hundred and sixty feet to the place of beginning-containing five and sixty-one hundredths acres, more or less."

Besides these two conveyances, J. A. Williamson and 'T. A. Walker, executed a Bond on the same day conditioned to convey to the State, two acres and nineteen hundredths, described as follows: "Beginning at a point $N$. eighteen degrees thirty-seven seconds $E$. If rom the $N$. $E$. corner of Capitol Square, distant one thousand five hundred and fiftyfour feet; thence $N$. fifteen degrees $W$. three hundred and eighteen feet; thence $N$. seventy-five degrees $F$, three hundred fect; thence $S$. fifteen degrees E. three hundred and eighteen feet; thence S. seventyfive degrees $W$. three hundred feet to the place of beginning-two and nineteen hundredths acres." This Bond is not recorded, but filed in the Secretary's office.

All of said Lands and Town Lots are situated in the City of Des Moines, upon beautiful wooded cminences, and the policy of the State should be to "spare the trees," protect and improve the grounds by a good, substantial fence, and otherwise, and guard against that vandalism which pervades so generally in this State to destroy, that the succeeding generation may have something to do in repairing their ravages. Better, far better, at less labor and expense, preserve the beautiful groves of native growth, than in after years expend greater sums to replace them.

T. S. PARVIN, Register.

\title{
CURATOR OF HISTORICAL DEPARTMENT AS TRUSTEE OF SPIRIT LAKE MASSACRE MEMORIAI, AND GROUNDS
}

Mr. E. R. Harlan, Curator,

Historical Department.

Dear Mr. Harlan:

The Executive Council at a meeting held August 10, 1921, adopted a resolution as follows:

Whereas, Chapter 333, Acts of the Thirty-seventh General Assembly provides for the custody of historic grounds by the office of the Curator of the Historical Department, and

Whereas, The Spirit Lake Massacre Monument and Grounds, until the recent death of Abbie Gardner Sharp were by courtesy maintained by Mrs. Sharp and are now without direct custody and oversight, and

Whereas, Among other things, it is necessary that the grounds be 
kept in a sightly condition and that the bronze tablets, through the ignorance of someone, have been coated with a preparation of black paint which should be skillfully removed and the monument and grounds hereafter maintained perpetualiy in a way appropriate to the spirit in which they were provided and dedicated; therefore

Resolved, That the Curator of the Historical Department be and he hereby is, subject to proper provisions approved in writing by the Board of Trustees of the Historical Department of Iowa, directed to assume and continue control and responsibility as Trustee of the State of Iowa for said monument and grounds.

The above resolution was unanimously adopted by the Council.

Yours very truly,

R. E. JOHNSON, Secretary.

\section{GEORGIA AND IOWA MARRIAGES, 1864}

World annals teem with instances of attachments of the sons and daughters of victors with sons and daughters of vanquished. Iowa and Georgia had their examples as evidenced in the marriage records of Clarke County, Iowa, by the returns following: FIRST RECORD BOOK OF MARRIAGES OF CLARKE COUNTY, IOWA

Office Provost Marshall

Rome Georgia, 15th Aug. 1864.

To Any Chaplain in the Armies of the United States.

\} GREETIN G.

By virtue of Authority in me vested, I hereby authorize you to unite in the Holy Bands of Wedlock, Pvt John Reynolds, 39th Inf Iowa Vol.g\& Miss Elizabeth Wallace, of Floyd Co. Ga.

By Order of

Brig Gen Wm. Vancleave

Josiah Rollins

Capt. \& Prvt Marshal

Floyd County, Ga., 17th $\Lambda$ ug 1864

By virtue of authority in me vested, Mr John Reynolds, Member of Company D 39th Iowa Infantry Vol \& Miss Elizabeth Wallace of Floyd County Georgia, have this day been united in the Holy Bands of Wedlock.

Eld. A. H. Chase

We the undersigned members of Company D 39th Iowa Infty Vol hereunto subscribe our names as witnesses to the above.

A. E. Chase

William L. Chaney

John C. Johnson 
Copyright of Annals of Iowa is the property of State of Iowa, by \& through the State Historical Society of Iowa and its content may not be copied or emailed to multiple sites or posted to a listserv without the copyright holder's express written permission. However, users may print, download, or email articles for individual use. 